\title{
COST EFFECTIVE AND AN EXPERIMENTAL STUDY ON MECHANICAL PROPERTIES OF CONCRETE BY USING TILE WASTAGES AND QUARRY DUST
}

\author{
Dr. Shanthala $B^{1} \&$ Surendra Nayak ${ }^{2}$ \\ 1 Assistant Professor, Department of Civil Engineering\& 2 student Department of Civil Engineering \\ Government Engineering College, Karwar, Karnataka.
}

\begin{abstract}
In India, large quantity of construction and demolition waste, including substantial amount of used concrete paving blocks and tiles, is produced in metropolitan cities every year. construction and demolition wastes are normally composed of concrete rubble, bricks, blocks and tiles, sand and dust, timber, plastics, cardboard and paper, and metals. Crushed concrete paver blocks, tiles and bricks, after separation from other construction and demolition waste and sieved, can be used as a substitute for natural coarse aggregates (CAs) in concrete or as a sub-base or a base layer in pavements or in the production of bricks and block. Amount of CA in concrete also plays a role in controlling compressive strength (CS) of concrete. Recycled aggregates from coal combustion by products are being used in construction sectors. From present research it is found that many waste materials cannot be disposed of by incineration. Use these wastages as an alternative for coarse aggregate in concrete will become one of the best waste management practices.
\end{abstract}

Keywords: coarse aggregates, Quarry Dust,Tiles, Concrete

I. INTRODUCTION

Currently India has taken a major initiative on developing the infrastructures such as express highways, power projects and industrial structures etc., to meet the requirements of globalization, in the construction of buildings and other structures concrete plays the rightful role and a large quantum of concrete is being utilized. River sand, which is one of the constituents used in the production of conventional concrete, has become highly expensive and scarce. In the backdrop of such a bleak atmosphere, there is large demand for alternative materials from industrial waste.

Concrete is an artificial material similar in appearance and properties to some natural limestone rock. It is a manmade composite, the major constituent being natural aggregate such as gravel, or crushed rock, sand and fine particles of cement powder all mixed with water. The concrete as time goes on through a process of hydration of the cement paste, producing a required strength to withstand the load. The use of coconut shell as coarse aggregate in concrete has never been a usual practice among the average citizens, particularly in areas where light weight concrete is required for non-load bearing walls, non-structural floors, and strip footings. Although coarse aggregate usually take about $50 \%$ of the overall self-weight of concrete. The cost of construction materials is increasing day by day because of high demand, scarcity of raw materials, and high price of energy. From the standpoint of energy saving and conservation of natural resources, the use of alternative constituents in construction materials is now a global concern. For this, the extensive research and development works towards exploring new ingredients are required for producing sustainable and environment friendly construction materials. The recycling of solid wastes in civil engineering applications has undergone considerable development over a very long time. The utilization of fly ash, blast furnace slag, recycled aggregates, red mud, Kraft pulp production residue, waste tea, etc., in construction materials shows some examples of the success of research in this area. Similarly, the recycling of hazardous wastes for use in construction materials and the environmental impact of such practices has been studied for many years. So In this project we are making the concrete with CA and FA alternatives like Mangalore tiles wastages and quarry dust respectively.

Common river sand is expensive due to excessive cost of transportation from natural sources. Also largescale depletion of these sources creates environmental problems. As environmental transportation and other constraints make the availability and use of river sand less attractive, a substitute or replacement product for concrete industry needs to be found. River sand is most commonly used fine aggregate in the production of concrete poses the problem of acute shortage in many areas. Whose continued use has started posing serious problems with respect to its availability, cost and environmental impact. In such a situation the Quarry rock dust can be an economic alternative to the river sand. Quarry rock dust can be defined as residue, tailing or waste material which is left after the extraction and processing of rocks to form fine particles less than $4.75 \mathrm{~mm}$. Usually, Quarry rock dust is used in large scale in the highways as a surface finishing material and also used for manufacturing of hollow blocks and lightweight concrete prefabricated elements. Use of Quarry rock dust as a fine aggregate in concrete draws serious attention of researchers and investigators. But it can be replaced by other alternatives such as use of Quarry dust instead of sand and wastage of Mangalore tiles for coarse aggregates. R. Ilangovana et al (2008) proposed a theory on concrete and this theory provide the feasibility of the usage of Quarry Rock Dust as hundred percent substitutes for Conventional Concrete. 
At the end of the study following conclusion are made Physical and chemical properties of quarry rock dust are satisfied the requirements of code provision in properties studies. Natural river sand, if replaced by hundred percent Quarry Rock Dust from quarries, may sometimes give equal or better than the reference concrete made with Natural Sand, in terms of compressive and flexural strength studies. The strength of Quarry Rock Dust concrete is comparatively 10-12 percent more than that of similar mix of Conventional Concrete. The Durability of Quarry Rock Dust concrete under sulphate and acid action is higher inferior to the Conventional Concrete. Permeability Test results clearly demonstrates that the permeability of Quarry Rock Dust concrete is less compared to that of conventional concrete. The water absorption of Quarry Rock Dust concrete is slightly higher than Conventional Concrete

Conclusion is that the replacement of natural sand with Quarry Rock Dust, as full replacement in concrete is possible. However, it is advisable to carry out trial casting with Quarry Rock Dust proposed to be used, in order to arrive at the water content and mix proportion to suit the required workability levels and strength requirement. However, more research studies are being made on Quarry Rock Dust concrete necessary for the practical application of Quarry Rock Dust as Fine Aggregate. M C Nataraja and Lelin Das (2011) proposed a theory on concrete and this theory provide the feasibility of the usage of broken tiles as hundred percent substitutes for Conventional Concrete. They have made certain conclusions after completion of the study and they are Trial concrete and mortar mixes are proportioned at w/c ratio of 0.5 to obtain synergy of all concrete ingredients due to interfacial bond and/or characteristic strength of CAs. When strength of mortar is greater than that of concrete strength, it is likely that failure would be predominantly by aggregate crushing. For specified strength of concrete, which is higher than that of characteristic strength of aggregate, compatible mortar strength is calculated by linear law of mixtures. To obtain that mortar strength, w/c ratio is calculated by generalized Abrams' Law. Broken Tiles taken as CAs can be used in place of conventional aggregates, provided, BT are proportioned in systematic way, though not for structural concrete economically. By limiting strength of concrete close to characteristic strength of BT, it would be possible to restrict mortar strength to minimize use of cement.

Maninder Kaur and Manpreet Kaur (2012) proposed a theory on concrete and this theory provide the feasibility of the usage of coconut shell as hundred percent substitutes for natural granite aggregate in concrete. They have made certain conclusions after completion of the study and they are use of coconut shells in cement concrete can help in waste reduction and pollution reduction. The need of the hour is to encourage the use of the waste products as construction materials in low-cost housing. It is also expected to serve the purpose of encouraging housing developers in investing these materials in house construction. The construction industries have identified many artificial and natural lightweight aggregates that have replaced conventional aggregates thereby reducing the size of structural members. This has brought immense change in the development of high rise structures using Light weight concrete. Coconut Shells are not commonly used in the construction industry but are often dumped as agricultural wastes. Coconut Shell Concrete can be used in rural areas and places where coconut is abundant and may also be used where the conventional aggregates are costly. Coconut shell concrete is also classified as structural lightweight concrete. It is concluded that the Coconut Shells are more suitable as low strength-giving lightweight aggregate when used to replace common coarse aggregate in concrete production.

Mohammad Abdur Rashid et al (2009) proposed a theory on concrete and this theory provide the feasibility of the usage of crushed bricks as hundred percent substitutes for natural granite aggregate in concrete. In Bangladesh and parts of West Bengal, India, where natural rock deposits are scarce, burnt clay bricks are used as an alternative source of coarse aggregate. In Bangladesh the use and performance of concrete made with broken brick as coarse aggregate are quite extensive and satisfactory. Clay can be burnt in its natural form as is done in brick-making and the product may be a source of coarse aggregate for concrete. Also in brick-making, a large number of bricks are rejected due to nonconformity with the required specifications. One such major nonconformity is the distorted form of brick produced due to the uneven temperature control in the kiln. These rejected bricks can also be a potential source of coarse aggregate. This would not only make good use of the otherwise waste material but would also help alleviate disposal problems. In spite of extensive use of brick aggregate concrete in this regions and the apparent satisfactory performance of the structures already built, no systematic investigation was conducted and properly documented. The current designs for brick aggregate concretes are based on intuition and accumulation of experience, rather than on sound experimental evidence. After completion of the entire study Abdul Rashid et al made certain conclusions and they are Crushed bricks may be used satisfactorily as coarse aggregate for making concrete, the strength of which is much higher than that of bricks considered. The unit weight of such concrete is around 130 pounds per cu $\mathrm{ft}$ which is about $13 \%$ lower than that of normal weight concrete. Similar to normal weight concrete a drastic reduction in the compressive strength of brick aggregate concrete due to the increase in water-cement ratio has been found. The rate of this strength reduction is higher for lower water-cement ratio. The cylinder compressive strength has been found about $90 \%$ of the corresponding cube compressive strength for brick aggregate concretes studied. The higher the compressive strength the higher is the ratio of cylinder to cube compressive strengths.

Daniel Yaw Osei and Emmanuel Nana Jackson (August 2012) proposed a paper on concrete. This paper reports on experimental investigations on the effects of replacing crushed granite in concrete with palm kernel shells on the strength, density and workability of concrete. The palm oil industry produces wastes such as palm kernel shells, palm oil fibers which are usually dumped in the open thereby impacting the environment negatively without any economic benefits. Palm kernel shells (PKS) are hard, 
carbonaceous and organic by- products of the processing of the palm oil fruit. PKS consists of small size particles, medium size particles and large size particles in the range 0-5mm, 5-10 mm and 10-15mm (Alengaram, Mahmud, Jumaat \& Shiraz, 2010). The shells have no commercial value, but create disposal and waste management problems. In Ghana, palm kernel shells are generally not used in construction. They are used as fuel by local blacksmiths and as fill material or as palliatives. Ndoke (2006) investigated the suitability of palm kernel shells as partial replacement for coarse aggregates in asphaltic concrete. Olutoge (2010) investigated the suitability of sawdust and palm kernel shells as replacement for fine and coarse aggregate in the production of reinforced concrete slabs. He concluded that $25 \%$ sawdust and palm kernel substitution reduced the cost of concrete production by $7.45 \%$. He also indicated the possibility of partially replacing sand and granite with sawdust and palm kernel shell in the production of lightweight concrete slabs. At the end of the study the following conclusions are made: There exists a high potential for the use of palm kernel shells as aggregates in the manufacture of lightly reinforced concrete. PKSC batched by volume replacement or weight replacement of coarse aggregate with palm kernel shells show similar trends in the variation of density, workability and strength with increase in percentage replacement. Loss of strength, workability, and density per in-crease in percentage replacement by PKS is higher for weight-batched concrete than for volume batched concrete. There are potential cost reductions in concrete production using palm kernel shells as partial replacement for crushed granite. Based on the results obtained, replacement of $8 \%$ crushed granite by palm kernels shell in volume-batched concrete can be used in reinforced concrete construction whereas replacement of $13 \%$ if crushed granite in weight batched concrete can be used in reinforced concrete construction. Palm kernel shell concrete batched by volume per-formed better than that batched by weight.

Mohammed Nadeem1 and Arun D. Pofale (2012) proposed a theory on Results of experimental investigations carried out to evaluate effects of replacing aggregate (coarse and fine) with that of slag on various concrete properties. At the end of the study following conclusions are made Compressive strength of concrete improved by 4 to $7 \%$ at all the $\%$ replacements of normal crushed coarse aggregate with crystallized slag. In case of replacements of fine aggregate, the strength improvement was notably observed at 30 to $50 \%$ replacement level by 4 to $6 \%$. It could be said that full substitution of slag aggregate with normal crushed coarse aggregate improved the flexure and split tensile strength at all replacements by 6 to $8 \%$ and in case of replacing fine aggregate with slag, the strength improvement was at 30 to $50 \%$ replacement levels by 5 to $6 \%$. The workability of concrete decreased with $100 \%$ replacements of normal crushed coarse aggregate with slag aggregate by about $30 \%$ in M20 grade and about $8 \%$ in M30 and M40 grade of concrete compared to control mix of concrete. The drop in workability could be attributed to porous and rough surface of slag aggregate which improved in higher grade of concrete due to availability of finer contents. The workability improved by $20 \%$ by replacing fine aggregate with granular slag up to $50 \%$ replacement level. It could be said that $100 \%$ replacements of crushed coarse aggregate with crystallized slag enhanced concrete density by 5 to $7 \%$ in all the concrete mixes and reduces concrete density by $3 \%$ in case of replacing fine aggregate with granular slag. The improvement in density was due to the higher unit weight of Crystallized slag aggregate which is $9 \%$ heavier than natural aggregate. Hence, it could be recommended that slag aggregate could be effectively utilized as coarse and fine aggregate in all concrete applications either as partial or full replacements of normal crushed coarse and natural fine aggregates.

\section{MATERIAL AND METHOD}

This high-performance blended cement is produced with pulverized clinker (53 grades) and the most consistent granulated blast furnace slag with more than $95 \%$ glass content. This provides much higher compressive strength than 53 grades OPC at 28 days. Separate grinding of Slag and clinker results in uniform particle size distribution.Better workability \& denser mortar.Higher ultimate strength, Reduced alkali aggregate reaction due to low alkali content. High soundness as endorsed by the extremely low values of expansion obtained through LeChatelier and Autoclave tests.Low C3A content increases resistance of the concrete to the sulphate attack.Protects against weather attack.Less porous \& impermeable concrete structures.Corrosion resistance concrete.Develops a gel-like structure which reduces permeability, making the structure less porous, thus increasing its durability.Lighter colored cement.
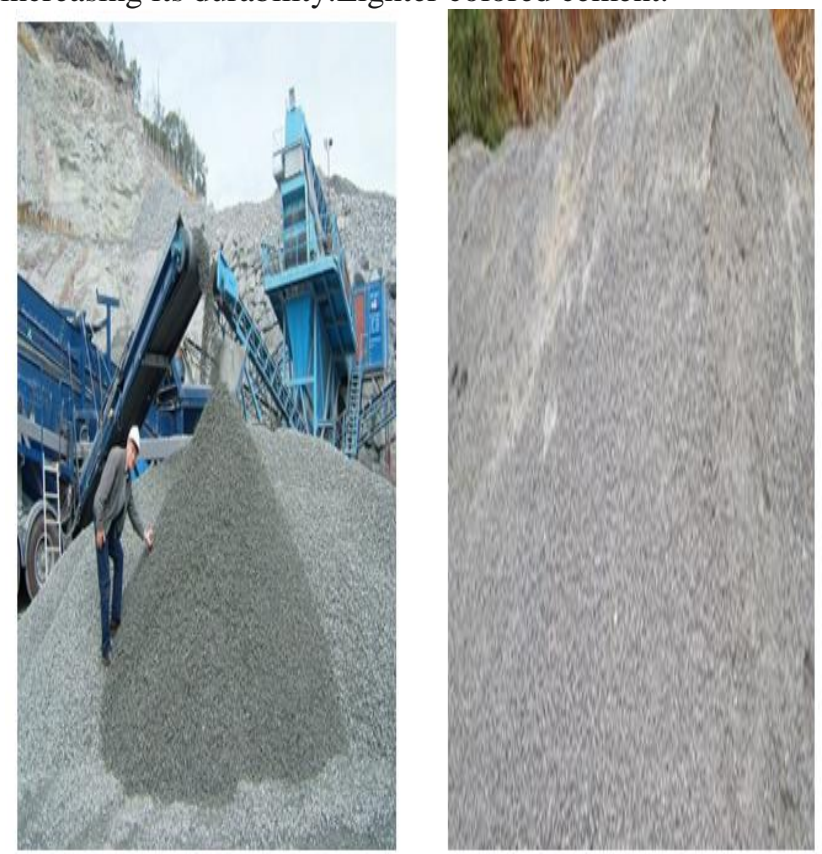

Fig.1. Production of quarry dust in stone crushing unit

PSC is easily replacing OPC and provides advantages for practically all types of the construction applicationsResidential Building, Complexes, RCC work, Multistoried buildings, Mass concrete works, underground concrete works like foundations, roofing and all types of plasters, masonry works, tile fixing work etc. Unique features of 
PSC make it suitable cement for heavy-duty structures like flyovers, dams, aqueducts \& marine structures, for producing asbestos cement products and also for sub soil constructions and structures in hostile soil environment with high salinity, moisture and harmful chemical agents. Common river sand is expensive due to excessive cost of transportation from natural sources. Also large-scale depletion of these sources creates environmental problems. As environmental transportation and other constraints make the availability and use of river sand less attractive, a substitute or replacement product for concrete industry needs to be found. River sand is most commonly used fine aggregate in the production of concrete poses the problem of acute shortage in many areas. Whose continued use has started posing serious problems with respect to its availability, cost and environmental impact. In such a situation the Quarry rock dust can be an economic alternative to the river sand. Quarry Rock Dust can be defined as residue, tailing or other non-voluble waste material after the extraction and processing of rocks to form fine particles less than $4.75 \mathrm{~mm}$. Usually, Quarry Rock Dust is used in large scale in the highways as a surface finishing material and also used for manufacturing of hollow blocks and lightweight concrete prefabricated Elements. Use of Quarry rock dust as a fine aggregate in concrete draws serious attention of researchers and investigators.

Rock is crushed to get coarse aggregate in quarries and in this process large volume of dust or fine particles of rock is generated. They are known as quarry dust. The dust obtained has properties similar to that of sand and can be used for construction purposes. Mangalore was the birth place of tiles and the tiles were used all over India hence were known as Mangalore tiles. It was first introduced in India by a German missionary, and these are fired clay tiles.

Since the opening of the Albuquerque tile factory, Mangalorean's have been actively involved in manufacturing these red Mangalore tiles. ${ }^{[}$In 1878, followed the Alvares tile factory established by Mr.SimonAlvares of Bombay at Mangalore. The tiles produced by the factory were in great demand throughout the Indian subcontinent and East Africa Abundant deposits of clay, plenty of firewood from the Western Ghats and cheap skilled labour helped the industry flourish. By the 1900s there were around 25 tile factories situated in and around Mangalore. By 1994 around 75 tile factories were present in Mangalore. As per the years 1991-1992 out of a selected 12 tile factories, 6 were owned by Hindus and the other 6 by Christians. The factories along with these tiles also manufactured materials such as ridges, limestone and bricks. In 2007, the industry suffered a loss with about 10 tile factories shutting down due to scarcity of raw materials like clay and as factories struggled to find skilled and cooperative workers.

There are 4 minor and 7 major tile industries functioning in Uttar kannada district. The individual production capacity of each industry ranges from 9000-16000 tiles per day .even though mixing, moulding burning and storing operations are carried out carefully by trained labourers, $3 \%$ of their daily production becomes waste .Therefore, it has been observed that nearly 9000 tiles are becoming waste from total 11 industries per day. So analyzing the annual wastages from those industries ,it is found to be 3285000 tiles per anum.40 broken tiles accommodates $1 \mathrm{~m}^{3}$ approximately and total volume of annual waste leading to $82125 \mathrm{~m} 3$. Annually this quantities of broken tiles are dumped on nearby cultivable land by industries .nowadays, people start opposing for dumping the wastes in their cultivable land.

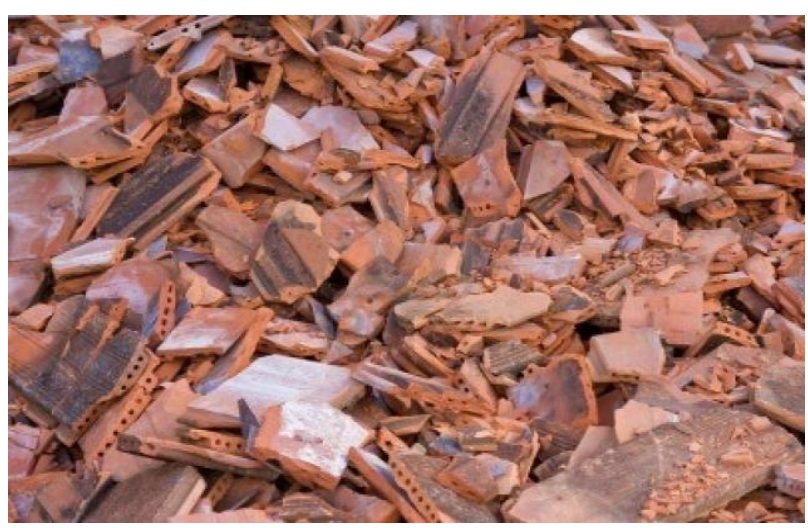

Fig.2. Broken tiles collections from tile industry

Because of that, industries start opposing their wastes along the sides of road for our project, broken tiles were taken from sides of $\mathrm{NH} 17$ which was dumped by BITCO tile industry situated near Shirali. Hence broken tiles are available in plenty and free of cost, it becomes easy for the collection of our project.

\subsection{PHYSICAL TEST}

To determine the desirable properties of aggregates and concrete cubes the following tests were carried out.

\subsubsection{Specific Gravity Test}

Specific gravity of the material may be defined as the ratio of weight of known volume of the material to the equal volume of water, both weights being measured at same standard temperature. It helps in calculating concrete mix design and to calculate comprising factor in connection with workability measurements.

Equipments: Pycnometer, Balance and Glass rod.

Procedure:Weigh a clean and dry pycnometer with its cap (W1), about1/3 of pycnometer is filled with aggregates and the weight (W2) is determined. The pycnometer is then filled with water including the sample and all air bubbles were removed. The weight (W3) was then determined. The sample was removed and the pycnometer was filled completely with water and weighed (W4) was determined.

Formulae:

Specific Gravity = (W2-W1) (W2-W1)- (W3-W4)

Where,

W1- weight of empty pycnometer

W2- weight of pycnometer+ sample in grams

W3- weight of pycnometer+ sample + water in grams

W4- weight of pycnometer+ water in grams 


\subsubsection{Sieve Analysis}

Sieve analysis is conducted to determine the particle size distribution in a sample3 of aggregate.

\section{Procedure:}

The aggregate used for making concrete are normally of maximum size $80 \mathrm{~mm}, 40 \mathrm{~mm}, 20 \mathrm{~mm}, 10 \mathrm{~mm}$, $4.75 \mathrm{~mm}, 2.36 \mathrm{~mm}, 1.18 \mathrm{~mm} 600$ micron, 300 micron and 150 micron. The aggregate fractions from $80 \mathrm{~mm}$ to $4.75 \mathrm{~mm}$ are termed as coarse aggregates and those fractions from $4.75 \mathrm{~mm}$ to 150 micron are termed as fine aggregates.

Grading pattern of a sample of C.A or F.A is assessed by sieving a sample successively through all the sieves mounted one over the other in order of size, with larger sieve on top. The material retained on each sieve after shaking, represents the fraction of aggregate coarser than the sieve in question and finer than the sieve above. Then the set of sieves are placed on sieve shaker for 10 minutes.

From the sieve analysis particle size distribution in a sample of aggregate is found out. Fineness modulus is an empirical factor obtained by adding the cumulative percentages of aggregate retained on each of the standard sieves ranging from $80 \mathrm{~mm}$ to 150 micron and dividing this sum by an arbitrary number 100.larger the figure coarser is the material.

\subsubsection{Compressive Strength Test}

This test is conducted to determine the strength of the concrete cubes. Concrete is very strong in compression. It is assumed that whole of compression will be taken up by the concrete while designing any RCC structure. The most important test for concrete is the compression test. This test is not only important from structural point of view but also other properties such as fatigue, impact, shrinkage, creep, deformation and thermal sensitivity bear some relationship with it.

Before placing the concrete in the mould, its interior surface and base plate should be lightly oiled. The test specimens should be made as soon as practicable after mixing the ingredients to a uniform color and in such a way as to produce full compaction of the concrete with neither segregation nor excessive bleeding.

\section{Procedure}

Take 3 cubes of same mix proportion. This bricks are kept at a temperature of $27 \pm 2^{\circ} \mathrm{C}$ for 24 hours. At the end of the period cubes are immersed in clean fresh water. The cubes are kept in water until time of testing. These cubes are tested for their compressive strength after 7 and 28 days curing in a compression testing machine, loading being uniform at the rate of $350 \mathrm{~kg} / \mathrm{cm}^{2} /$ minute. The load at failure is noted and compressive strength is calculated.

\section{Formulae:}

Compressive strength $=$

$$
\mathrm{P}
$$
$. \mathrm{N} / \mathrm{mm}^{2}$

Where,

\section{P- Load in N}

\subsubsection{Water Absorption Test}

This test is performed to determine water absorption of quarry dust and broken Mangalore tile pieces. The moisture present in aggregate sample may be in the form of absorbed moisture or surface moisture or both. When all the pores in the aggregates are full and no water on the surface the aggregate are said to be saturated surface dry. If aggregate used for concrete are of this type they will not contribute any water to the cement paste and water cement ratio will remain same.

If the aggregates contain surface moisture they will contribute some water to the dilution of cement paste and this will increase water cement ratio and strength will go down. On the other hand if aggregates are dry they will absorb water from cement paste and hence reducing the water cement ratio consequently workability of the mix is affected.

\section{Procedure}

Certain quantity of sample is weighed. Sample has to soak it in water for $24 \mathrm{hrs}$ and weighed i.e. W1. Transfer this into a tray and is oven dried with the help of thermostatically controlled heater. Allow the oven dried sample to cool to lab temperature and take the weight (W2).

Formulae:

$$
\text { Water content } \quad \mathrm{w}=\frac{(\mathrm{W} 1-\mathrm{W} 2)}{\mathrm{W} 2} \times 100
$$

Percentage of moisture content present in the sample $=$

\subsubsection{Slump Test}

Slump test gives an idea about consistency of concrete mix and indirectly measures the workability of concrete mix taken. Workability is the ease and homogeneity with which concrete can be mixed, transported, placed, compacted and finished.

Some of the important factors that affect the workability of concrete are

- Relative quantities of paste and aggregates

- Plasticity of paste itself

- Maximum size and grading of aggregates

- Shape and surface characteristics of aggregate particles

\section{Procedure}

The sample of freshly mixed concrete is taken. The internal surface of the mould is thoroughly cleaned and freed from any set concrete before commencing the test. The mould is placed on a level smooth and non absorbent surface such as metal plate. The mould is filled in 4 equal layers with the fresh sample. Each layer is compacted with 25 strokes of $16 \mathrm{~mm}$ steel rod, $600 \mathrm{~mm}$ long and bullet pointed at the bottom. The strokes should be applied uniformly over the entire area and with such a force that the rod just penetrates the full depth of layer being compacted. Once the mould is fully filled the surplus concrete is struck off with a trowel or tamping rod. The mould is vertically lifted with utmost care. The operat11ions are carried out at a place free from vibration and within a period of 2 minutes after sampling.

The slump measured is recorded in terms of millimeters of subsidence of specimen during test. Slump specimen who collapses or streams off laterally gives incorrect result and if this occurs the test is repeated with another sample.

\subsubsection{Normal Consistency Test}

Normal consistency is defined as the amount of water required to convert dry cement into paste. It is 
expressed as percentage water by weight of cement. The normal consistency helps in determining the water required (to be mixed with cement) for tests like settings time and strength test.

\section{Procedure}

Sample for the test is prepared by mixing $300 \mathrm{gm}$ of cement (passing through $850 \mu$ sieve) with a trial percentage of water as $28 \%$ by weight of cement. The paste so prepared is filled in the mould completely and air is expelled from the cement mass by gently tapping the mould. The mould is placed at the platform of Vicat apparatus, which is attached with the plunger to test the depth of penetration. The plunger is brought to the surface of the cement paste, centrally and plunger is released to sink it into the cement paste. The depth of penetration is noted. The test is repeated for higher percentage of water say $30,32,33 \ldots$.. etc till the plunger penetrates at a point 5 $7 \mathrm{~mm}$ from the bottom of the scale (Unpenetrated depth). The percentage water by weight of cement at the required penetration is called Normal Consistency.

\subsubsection{Setting Time Test}

In order that concrete may be placed in position conveniently, it is necessary that the initial setting time of cement is not too quick and after it has been laid, hardening should be rapid so that the structure can be made use of as early as possible. The initial set is a stage in the process of hardening after which any crack that may appear will not reunite. The Cement is said to finally set when it has obtained sufficient strength and hardness.

\section{Procedure}

The cement sample is prepared by gauging the $300 \mathrm{gms}$ of cement with $0.85 \mathrm{P}$ water, where $\mathrm{P}$ is normal consistency as known earlier. The stop watch is started as soon as the cement is mixed with water. The paste so prepared is filled in the mould completely and air is expelled by cement mass by gently tapping the mould. The mould is placed at the platform of Vicat apparatus, which is attached with initial setting time needle. The needle is brought to the surface of the cement paste, and it is released to penetrate into the cement paste. Initially it is found that the needle penetrates completely into the cement mass.

The penetration of the needle is noted at regular intervals say $10 \mathrm{~min}, 15 \mathrm{~min}, 12 \mathrm{~min}$, etc till the needle penetrated at a point $5-7 \mathrm{~mm}$ from the bottom of the scale (Unpenetrated depth).The time at which the required penetration takes place, is Initial Setting time. For Final Setting time, the same sample and procedure is used but with the different needle called needle for final setting time with circular cutting edge and an end projection of $0.5 \mathrm{~mm}$ The cement is said to be finally set if the needle makes impression on the cement paste, whereas circular cutting edge fails to do. The time at which this condition is achieved is called Final Setting Time.

\subsubsection{Crushing Value Of Coarse Aggregate}

The strength of the coarse aggregate is assessed by aggregate crushing test. The aggregate crushing value provides a relative measure of resistance of crushing under a gradually applied compressive load. Aggregates used in road construction shall be strong enough to resist crushing under traffic wheel load. If the aggregates are weak, then stability of pavement structure is likely to be adversely effected. So, aggregates with low crushing value should be preferred for road construction.

\section{Procedure:}

The test sample was collected by sieving the aggregates. The aggregates that passed through $12.5 \mathrm{~mm}$ IS sieve and retained on $10 \mathrm{~mm}$ IS sieve were collected. The cylinder of the test apparatus was placed in position on the base plate. The aggregates were measured in cylindrical metal measure. The aggregates were filled in metal measure in three layer with 25 no of tamping with a tamping rod and net weight of aggregate was found. The aggregates were transferred in the test apparatus (in cylinder) in three layers, and each layer was given 25 no. of tamping with tamping rod.

The total depth of the material after tamping shall however be $10 \mathrm{~cm}$. The surface of aggregate was leveled and the plunger was placed in position. Load was applied on the plunger at a uniform rate by Compression testing machine so that the total load of 40 tones was reached in 10 minutes. The load was then released, and material was removed from the cylinder and sieved through $2.36 \mathrm{~mm}$ sieve. The fraction that passes through the sieve was weighed.

\section{Formulae}

Aggregate crushing value $=\left(\mathrm{W}_{2} / \mathrm{W}_{1}\right) \times 100$

Where,

W1-Total weight of sample

$\mathrm{W} 2$ = Weight of crushed material passing through $2.36 \mathrm{~mm}$ sieve size

\subsubsection{Bulk Density Test}

Denseness of material can be finding with the help of this test. Degree of consistency measured by the quantity of mass per unit volume. The bulk density of an aggregate gives valuable information regarding the shape and grading of the aggregate. For a given specific gravity the angular aggregate show a lower bulk density.

Procedure: Take container and then find its dimensions. Take the weight of container alone. Samples were filled in metal measure in three layers with 25 no of tamping with a tamping rod and net weight of sample was found.

Formulae: Bulk density = Mass of sample/ Volume of container

\subsubsection{Two Point Loading Test On Beam}

Main aim of doing two point loading test is to determine the modulus of rupture of given concrete beam specimen by two point loading. Flexural strength of concrete is known by its modulus of rupture which is the extreme fiber in bending. There are two methods of finding flexural tension; they are central point loading and two point loading. IS 516-1959 specifies two point loading. The standard size of modulus in which concrete is to be cast for testing are, $15 \times 15 \times 70 \mathrm{~cm}$ or $10 \times 10 \times 50 \mathrm{~cm}$.

\section{Procedure}

Dimensions of beam are noted. The beam is divided into three equal parts. The beam is mounted on universal testing machine over the rollers. Two more rollers are kept on beam in the middle third portion .Loading is applied gradually over the two rollers till the specimen fails. The distance between line of fracture and the nearest support is noted. The load at failure is recorded from dial gauge.

Formulae 
If a is greater than $20 \mathrm{~cm}$ for $15 \mathrm{~cm}$ specimen or greater than $13.3 \mathrm{~cm}$ for $10 \mathrm{~cm}$ specimen then,

Modulus of rupture $\mathrm{fb}=\left(\mathrm{PL} / \mathrm{bd}^{2}\right)$

When a is between $20 \mathrm{~cm}$ and $17 \mathrm{~cm}$ for $15 \mathrm{~cm}$ specimen or $\mathrm{b} / \mathrm{w} 13.3$ and $11 \mathrm{~cm}$ for $15 \mathrm{~cm}$ specimen ,then

Modulus of rupture $=3 \mathrm{~Pa} / \mathrm{bd}^{2}$

\subsection{Mix Design Calculation}

Design 1 is calculated as per IS10262 for $\mathrm{M}_{20}$

\section{Solution:}

Step 1:

Target strength $=\mathrm{fck}+1.65 \mathrm{~S}$

$$
\begin{gathered}
=20+1.65 \times 4 \\
=26.6 \mathrm{mpa}
\end{gathered}
$$

\section{Step 2:}

Selection of $w / c$ ratio

Max w/c ratio from IS456-2000 is 0.5

Adopt w/c ratio $=0.44<0.5$

Hence $\mathrm{k}$

\section{Step 3:}

Selection of water content and fine to total aggregate ratio

From table number 4 of IS 10262, for $20 \mathrm{~mm}$ maximum size aggregate, fine aggregate conforming to grading zone II water content per cubic meter of concrete $=186 \mathrm{~kg} / \mathrm{m}^{3}$ for $\mathrm{w} / \mathrm{c}$ ratio $=0.6$, and workability of 0.80 and fine aggregate content as percentage of total aggregate by absolute volume $=35 \%$. For change in value in water-cement ratio, compacting factor, fine aggregate belonging to zone II, following adjustment is required.

Thus required water content is $186+$ $(3 \times 186 / 100)=191.58 \mathrm{~kg} / \mathrm{m}^{3}$ and required fine aggregate content as $\%$ of total aggregate is $35-3.2=31.8 \%$

\section{Steps 4:}

Calculation of cement content

$\mathrm{W} / \mathrm{C}$ ratio $=0.44$

Cement content $=191.58 / 0.44$

$$
=435.4 \mathrm{~kg} / \mathrm{m}^{3}
$$

Take cement content $435.4 \mathrm{~kg} / \mathrm{m}^{3}>250 \mathrm{~kg} / \mathrm{m}^{3}$

(From table 5 of IS 456, min cement content for severe exposure condition is $250 \mathrm{~kg} / \mathrm{m}^{3}$ )

\section{Step 5:}

Estimation of entrapped air:

As per table number 3 of IS code 10262, for maximum size aggregate of $20 \mathrm{~mm}$ the entrapped air is $2 \%$

\section{Step 6:}

Proportion of volume of CA and FA content

$$
\begin{aligned}
\mathrm{V} & =\left[\mathrm{w}+(\mathrm{C} / \mathrm{sc})+(1 / \mathrm{p}) \times\left(\mathrm{f}_{\mathrm{a}} / \mathrm{s}_{\mathrm{fa}}\right)\right] / 1000 \\
\mathrm{C}_{\mathrm{a}} & =\{(1-\mathrm{p}) / \mathrm{p}\} \times \mathrm{f}_{\mathrm{a}} \times\left(\mathrm{s}_{\mathrm{ca}} / \mathrm{s}_{\mathrm{fa}}\right)
\end{aligned}
$$

Where,

$\mathrm{V}=\mathrm{absolute}$ volume of concrete $=1 \mathrm{~m}^{3}-$ of volume entrapped air,

$\mathrm{W}=$ mass of water,

$\mathrm{C}=$ mass of cement,

$\mathrm{S}_{\mathrm{c}}=$ specific gravity of cement,

$\mathrm{p}=$ ratio of fine aggregate to total aggregate by absolute volume.

$\mathrm{f}_{\mathrm{a}}$ and $\mathrm{C}_{\mathrm{a}}$ are total mass of fine and coarse aggregates $/ \mathrm{m}^{3}$ of concrete respectively.

$\mathrm{S}_{\mathrm{fa}}$ and $\mathrm{S}_{\mathrm{ca}}$ are specific gravity of fine and coarse aggregate respectively.

$$
\begin{aligned}
& 0.98=[191.58+(435.4 / 2.9)+(1 / .318) x \\
& \left.\left(f_{a} / 2.637\right)\right] / 1000
\end{aligned}
$$

Solving, $\mathrm{f}_{\mathrm{a}}=535.24 \mathrm{~kg} / \mathrm{m}^{3}$

$\mathrm{C}_{\mathrm{a}}=\{(1-.318) / .318\} \times 535.24 \times(2.121 / 2.637)$

Solving, $\mathrm{C}_{\mathrm{a}}=923.28 \mathrm{~kg} / \mathrm{m}^{3}$

\begin{tabular}{|c|c|c|c|}
\hline \multicolumn{3}{|l|}{ Therefore the mix proportion for $1 \mathrm{~m}^{3}$ of concrete is } \\
\hline Water & Cement & Fine aggregate & $\begin{array}{l}\text { coarse } \\
\text { aggregate }\end{array}$ \\
\hline 191.58 & 435.4 & 535.24 & 923.28 \\
\hline 0.44 & 1 & 1.229 & 2.12 \\
& & & \\
\hline
\end{tabular}

(i) Total volume of concrete $=0.018 \mathrm{~m}^{3}$

(j) Quantity of materials required is:

Coarse aggregates $=(0.0185 / 0.980) \times 923.28$

$$
=17.42 \mathrm{~kg}
$$

Fine aggregates $=(0.0185 / 0.980) \times 535.24$

$$
=10.104 \mathrm{~kg}
$$

Cement $=(0.0185 / 0.980) \times 435.4$ 


$$
\begin{aligned}
& =8.219 \mathrm{~kg} \\
\text { Water } & =8.219 \times 0.44 \\
& =3.616 \mathrm{lt}
\end{aligned}
$$

Extra water to be added for absorption in case of CA, at $13.50 \%=17.42 \times 0.135$

$$
=2.351 \mathrm{lt}
$$

Extra water to be added for absorption in case of FA, at $0.851 \%=10.104 \times .0 .00851$

$$
=0.0859 \mathrm{lt}
$$

Actual quantity of water to be added $=3.616+2.351+$ 0.0859

$$
=6.0529 \mathrm{lt}
$$

Actual quantity of CA required $=17.42-2.351$

$$
=15.069 \mathrm{~kg}
$$

Actual quantity of FA required $=10.104-0.00851$

$$
=10.095 \mathrm{~kg}
$$

DESIGN 2 is calculated as per IS10262 for $\mathrm{M}_{15}$ Solution:

\section{Step 1:}

Target strength $=\mathrm{fck}+1.65 \mathrm{~S}$

$$
\begin{gathered}
=15+1.65 \times 3.5 \\
=20.775 \mathrm{mpa}
\end{gathered}
$$

\section{Step 2:}

Selection of w/c ratio

Max w/c ratio from IS456-2000 is 0.5

Adopt $\mathrm{w} / \mathrm{c}$ ratio $=0.49<0.5$

Hence k

\section{Step 3:}

Selection of water content and fine to total aggregate ratio

From table number 4 of IS 10262, for $20 \mathrm{~mm}$ maximum size aggregate, fine aggregate conforming to grading zone II water content per cubic meter of concrete $=186 \mathrm{~kg} / \mathrm{m}^{3}$ for $\mathrm{w} / \mathrm{c}$ ratio $=0.6$, and workability of 0.80 and fine aggregate content as percentage of total aggregate by absolute volume $=35 \%$. For change in value in water-cement ratio, compacting factor, fine aggregate belonging to zone II, following adjustment is required.

Thus required water content is $186+(3 \times 186 / 100)=191.58$ $\mathrm{kg} / \mathrm{m}^{3}$ and required fine aggregate content as \% of total aggregate is $35-2.2=32.8 \%$

\section{Steps 4:}

Calculation of cement content $\mathrm{W} / \mathrm{C}$ ratio $=0.49$

Cement content $=191.58 / 0.49$

$$
=390.97 \mathrm{~kg} / \mathrm{m}^{3}
$$

Take cement content $390.97 \mathrm{~kg} / \mathrm{m}^{3}>250 \mathrm{~kg} / \mathrm{m}^{3}$

(From table 5 of IS 456, min cement content for severe exposure condition is $250 \mathrm{~kg} / \mathrm{m}^{3}$ )

\section{Step 5:}

Estimation of entrapped air:

As per table number 3 of IS code 10262, for maximum size aggregate of $20 \mathrm{~mm}$ the entrapped air is $2 \%$

\section{Step 6:}

Proportion of volume of CA and FA content

$$
\begin{aligned}
& \mathrm{V}=\left[\mathrm{w}+(\mathrm{C} / \mathrm{sc})+(1 / \mathrm{p}) \times\left(\mathrm{f}_{\mathrm{a}} / \mathrm{s}_{\mathrm{fa}}\right)\right] / 1000 \\
& \mathrm{C}_{\mathrm{a}}=\{(1-\mathrm{p}) / \mathrm{p}\} \times \mathrm{f}_{\mathrm{a}} \times\left(\mathrm{s}_{\mathrm{ca}} / \mathrm{s}_{\mathrm{fa}}\right)
\end{aligned}
$$

Where,

$\mathrm{V}=$ absolute volume of concrete $=1 \mathrm{~m}^{3}-$ of volume entrapped air,

$\mathrm{W}=$ mass of water,

$\mathrm{C}=$ mass of cement,

$\mathrm{S}_{\mathrm{c}}=$ specific gravity of cement,

$\mathrm{p}=$ ratio of fine aggregate to total aggregate by absolute volume.

$\mathrm{f}_{\mathrm{a}}$ and $\mathrm{C}_{\mathrm{a}}$ are total mass of fine and coarse aggregates $/ \mathrm{m}^{3}$ of concrete respectively.

$\mathrm{S}_{\mathrm{fa}}$ and $\mathrm{S}_{\mathrm{ca}}$ are specific gravity of fine and coarse aggregate respectively.

$0.98=[191.58+(390.97 / 2.9)+(1 / .328) x$ $\left.\left(\mathrm{f}_{\mathrm{a}} / 2.637\right)\right] / 1000$

$$
\begin{aligned}
& \text { Solving, } \mathrm{f}_{\mathrm{a}}=565.324 \mathrm{~kg} / \mathrm{m}^{3} \\
& \mathrm{C}_{\mathrm{a}}=\{(1-.328) / .328\} \times 565.324 \times(2.121 / 2.637) \\
& \text { Solving, } \mathrm{C}_{\mathrm{a}}=931.58 \mathrm{~kg} / \mathrm{m}^{3}
\end{aligned}
$$

Therefore, the mix proportion for $1 \mathrm{~m}^{3}$ of concrete is

\begin{tabular}{|l|l|l|l|}
\hline Water & Cement & $\begin{array}{l}\text { Fine } \\
\text { Aggregate }\end{array}$ & $\begin{array}{l}\text { Coarse } \\
\text { Aggregate }\end{array}$ \\
\hline 191.58 & 390.97 & 565.324 & 931.58 \\
\hline 0.49 & 1 & 1.44 & 2.38 \\
\hline
\end{tabular}

(i) Total volume of concrete $=0.018 \mathrm{~m}^{3}$

(j) Quantity of materials required is:

Coarse aggregates $\quad=(0.0185 / 0.980) \mathrm{x}$ 931.58

$$
=17.58 \mathrm{~kg}
$$



565.324

Fine aggregates

$$
=(0.0185 / 0.980) \quad \mathrm{x}
$$$$
=10.67 \mathrm{~kg}
$$

$$
\text { Cement } \quad=(0.0285 / 0.980) \mathrm{x}
$$

390.97

$$
\begin{aligned}
& =7.380 \mathrm{~kg} \\
\text { Water } & =7.380 \times 0.49 \\
& =3.616 \mathrm{lt}
\end{aligned}
$$

Extra water to be added for absorption in case of CA, at $13.50 \%=17.58 \times 0.135$

$$
=2.37 \mathrm{lt}
$$

Extra water to be added for absorption in case of FA, at $0.851 \%=10.67 \times .0 .00851$

$$
=0.090 \mathrm{lt}
$$

Actual quantity of water to be added $=$

$3.616+2.37+0.090$

$$
\begin{array}{ll} 
& =6.076 \mathrm{lt} \\
\text { Actual quantity of CA required } & =17.58-2.37 \\
& =15.21 \mathrm{~kg} \\
\text { Actual quantity of FA required } & =10.67- \\
0.090 & =10.58 \mathrm{kgs}
\end{array}
$$

\section{RESULTS AND DISCUSSION}

Table.1 Specific Gravity Test On Coarse Aggregates

\begin{tabular}{|c|c|c|c|}
\hline Particulars & Trial 1 & Trial 2 & Trial 3 \\
\hline $\begin{array}{c}\text { Weight of the } \\
\text { container (w1) } \\
\text { Gm }\end{array}$ & 3080 & 3080 & 3080 \\
\hline $\begin{array}{c}\text { Weight of the } \\
\text { container + tile } \\
\text { aggregate(w2) } \\
\text { Gm }\end{array}$ & 6010 & 6025 & 6150 \\
\hline $\begin{array}{c}\text { Weight of container+ } \\
\text { tile aggregate + water } \\
\text { (w3) }\end{array}$ & 7580 & 7590 & 7680 \\
\hline $\begin{array}{c}\text { Weight of the } \\
\text { container + water } \\
\text { (w4) }\end{array}$ & 6040 & 6040 & 6040 \\
\hline $\begin{array}{c}\text { Specific Gravity of } \\
\text { Coarse Aggregate }\end{array}$ & 2.107 & 2.11 & 2.146 \\
\hline
\end{tabular}

Specific Gravity =

$\mathrm{W} 2-\mathrm{W} 1$

(W2 - W1)-(W3-W4)

Average specific gravity of coarse aggregate $=\mathbf{2 . 1 2 1}$

Table.1.2 Specific Gravity Test On Fine Aggregates

\begin{tabular}{|c|c|c|c|}
\hline Particulars & Trial 1 & Trial2 & Trial 3 \\
\hline $\begin{array}{c}\text { Weight of the } \\
\text { pycnometer (w1) } \\
\text { Gm }\end{array}$ & 476 & 476 & 476 \\
\hline $\begin{array}{c}\text { Weight of the } \\
\text { pycnometer + quany } \\
\text { dust (w2) } \\
\text { Gm }\end{array}$ & 996 & 813 & 785 \\
\hline $\begin{array}{c}\text { Weight of the } \\
\text { pycnometer +quary } \\
\text { dust + water (w3) } \\
\text { Gm }\end{array}$ & 1583 & 1471 & 1452 \\
\hline $\begin{array}{c}\text { Weight of the } \\
\text { pycnometer + water } \\
\text { (w4) }\end{array}$ & 1260.5 & 1471 & 1260.5 \\
\hline $\begin{array}{c}\text { Specific Gravity of } \\
\text { Coarse Aggregate }\end{array}$ & 2.632 & 2.66 & 2.62 \\
\hline
\end{tabular}

Specific Gravity $=\quad \underline{\mathrm{W} 2}-\mathrm{W} 1$

$$
\text { (W2 - W1)-(W3-W4) }
$$

Average specific gravity of coarse aggregate $=\mathbf{2 . 6 3 7}$

Table.1.2 Sieve Anlaysis

\begin{tabular}{|c|c|c|c|c|c|}
\hline Sl No & Sieve size & $\begin{array}{c}\text { Wtretained } \\
(\mathbf{g})\end{array}$ & $\begin{array}{c}\text { Cumulative } \\
\text { wt retained }\end{array}$ & $\begin{array}{c}\text { Cumulative } \\
\% \text { wt } \\
\text { retained }\end{array}$ & $\begin{array}{c}\text { Cumulative } \\
\% \text { finer }\end{array}$ \\
\hline 1 & $4.75 \mathrm{~mm}$ & 11 & 11 & 1.1 & 98.9 \\
\hline 2 & $2.36 \mathrm{~mm}$ & 21 & 32 & 3.2 & 96.8 \\
\hline 3 & $1.18 \mathrm{~mm}$ & 202.5 & 234.5 & 23.42 & 76.58 \\
\hline 4 & $0.6 \mathrm{~mm}$ & 253 & 487.5 & 48.75 & 51.25 \\
\hline 5 & $0.3 \mathrm{~mm}$ & 264.5 & 752 & 75.2 & 24.8 \\
\hline 6 & $0.15 \mathrm{~mm}$ & 208 & 960 & 96 & 4 \\
\hline 7 & $0.075 \mathrm{~mm}$ & 25 & 985 & 98.5 & 1.5 \\
\hline 8 & Pan & 15 & 1000 & 100 & 0 \\
\hline & Total & 1000 & & 346.17 & \\
\hline
\end{tabular}


Fineness modulus $=\underline{346.17}=\mathbf{3 . 4 6}$ 100

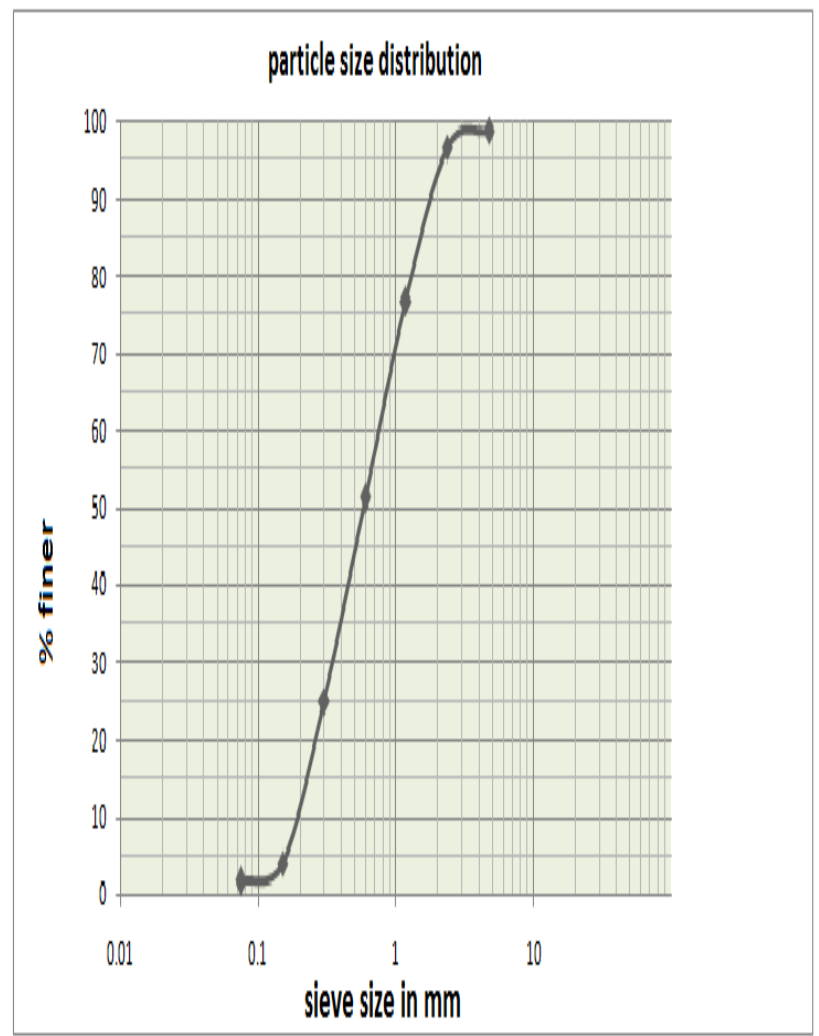

Fig.3. Sieve Anlaysis

Table.3. Water Absorption Test On Coarse Aggregates

\begin{tabular}{|c|c|c|}
\hline Particulars & Triall & Trial2 \\
\hline Wt of wet sample (gn) & 1125.78 & 1130.78 \\
\hline $\begin{array}{l}\text { Wt of dry sample } \\
(\operatorname{gnn})^{8}\end{array}$ & 991.86 & 996.86 \\
\hline \% of water absontion & 13.5 & 13.43 \\
\hline
\end{tabular}

$\%$ of water absorption $=((\mathrm{w} 1-\mathrm{w} 2) / \mathrm{w} 1) \times 100$

Avg $\%$ of water absorption $=13.46$
Tbale 3.1 Water Absorption Test On Fine Aggregates

\begin{tabular}{|c|c|c|}
\hline $\begin{array}{c}\text { Wt of wet } \\
\text { sample }\end{array}$ & $464 \mathrm{~g}$ & $4843 \mathrm{~g}$ \\
\hline $\begin{array}{c}\text { Wt of Dry } \\
\text { sample }\end{array}$ & $460 \mathrm{~g}$ & $460 \mathrm{~g}$ \\
& & \\
\hline $\begin{array}{l}\text { \% of water } \\
\text { absorption }\end{array}$ & 0.869 & 0.833 \\
& & \\
\hline
\end{tabular}

$\%$ of water absorption $=((\mathrm{w} 1-\mathrm{w} 2) / \mathrm{w} 1) \times 100$

Avg \% of water absorption $=0.851 \%$

Table.4.Bulk Density Of Coarse Aggregate

Container dimensions:

Height $\mathrm{h}=17 \mathrm{~cm}$

Diameter $\mathrm{d}=15 \mathrm{~cm}$

Volume $=3004.14 \mathrm{~cm}^{3}$

Wt of container +Tile aggregate 6170 gms

Wt. of Container $3080 \mathrm{gm}$

Wt of Aggregate $3090 \mathrm{gm}$

Density $=$ mass of aggregate/ volume of container

Density $=3090 / 3004.14$

$=1.028 \mathrm{~g} / \mathrm{cc}$

Table 4.1 Bulk Density Of Fine Aggregate

Container dimensions:

Height $\mathrm{h}=17 \mathrm{~cm}$

Diameter $\mathrm{d}=15 \mathrm{~cm}$

Volume $=3004.14 \mathrm{~cm}^{3}$

\begin{tabular}{|c|c|}
\hline Whafcomiamertquany dust & $8000 \mathrm{~g}$ \\
\hline 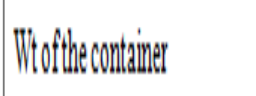 & $3000 \mathrm{mg}$ \\
\hline Whofoualny dust & $5010 \mathrm{gm}$ \\
\hline
\end{tabular}


Density $=$ mass of aggregate/ volume of container

Density $=5420 / 3004.14$

$$
=1.804 \mathrm{~g} / \mathrm{cc}
$$

Table.5 Crushing Test On Coarse Aggregate

\begin{tabular}{|c|c|}
\hline ntofthe oy dinder & $20 \mathrm{gm}$ \\
\hline 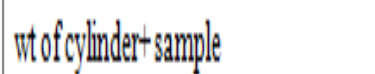 & $1980 \mathrm{gm}$ \\
\hline Thofamplewl & $1730 \mathrm{mg}$ \\
\hline $\begin{array}{l}\text { Wtofcushedmatenal passingthough } \\
236 \text { mmitever? }\end{array}$ & $733 \mathrm{gg}$ \\
\hline
\end{tabular}

Aggregate crushing value $=(\mathrm{w} 2 / \mathrm{w} 1) \times 100$

$$
=42.4 \%
$$

\begin{tabular}{|c|c|}
\hline Water Content $(0)$ & Cupenetrated Depth \\
\hline 30 & 25 \\
\hline 32 & 10 \\
\hline 33 & $j$ \\
\hline
\end{tabular}

Table.6 Normal Consistency Test

Normal Consistency $=33 \%$
Table.6.1 Initial Setting Time Test

Wt of cement $\quad=300 \mathrm{gm}$

Normal consistency of cement $(\mathrm{p})=33 \%$

Amount of water added $\quad=0.85 \mathrm{p} \%$

$=84.15 \mathrm{ml}$

\begin{tabular}{|c|c|c|}
\hline S. No. & Time n min & Tnpentrated depth \\
\hline 1 & 0 & 0 \\
\hline 2 & 10 & 1 \\
\hline 3 & 20 & 2 \\
\hline 4 & 30 & 2 \\
\hline 5 & 40 & 2 \\
\hline 6 & 50 & 2 \\
\hline 7 & 60 & 2 \\
\hline 8 & 70 & 3 \\
\hline 9 & 80 & 6 \\
\hline
\end{tabular}

Initial setting time $=80 \mathrm{~min}$

Final setting time $=210 \mathrm{~min}$

\section{CONCLUSION}

The tile brick concrete can be used to make concrete where compressive strength is less than 20 and $15 \mathrm{~N} / \mathrm{mm}^{2}$. The proposed concrete is having lower $\%$ of water absorption hence can be used in parapet walls and compound walls. The cost of proposed concrete is less compared to that of conventional concrete but slightly more (about 25\%) in comparison with laterite stone and cement solid block but it is viable considering strength(about 50\%) and water absorption aspects. To increase the strength of proposed concrete the tile aggregates can be coated with cement slurry or cement sand slurry so that the crushing strength of aggregate may be increased which may cause increase in compressive strength of concrete.

\section{REFERENCES}

[1] M. Kaur et al," A review on utilization of coconut shell as coarse aggregates in mass concrete", 'International journal of applied Engineering research,', vol. 7 page no.11 (2012).

[2] M. Ariful Islam et al," Properties of higher strength concrete made with crushed brick as coarse aggregate",' Journal of Civil Engineering', vol 37(1), page no 43-52 (2009). 
[3] M. Nadeem et al," Experimental investigation of using slag as an alternative to normal aggregates (coarse and fine) in concrete", ' International journal of Civil and Structural Engineering', volume 3, no 1, 2012.

[4] R. Ilangovana et al'," Strength and durability properties of concrete containing quarry rock dust as fine aggregate", "ARPN journal of engineering and applied sciences', vol. 3, no. 5, October 2008.

[5] D. Yaw Osei et al'," Experimental study on palm kernel shells as coarse aggregates in concrete", International journal of scientific \& Engineering research', volume 3, issue 8, August-2012.

[6] M .C. Nataraj et al'," A simplified mix proportioning for cement based composites with crushed tile waste aggregate", 'Journal of scientific \& Industrial research', vol. 70, May 2011, page no 385-390. 